\title{
PENGARUH PROFITABILITAS, SIZE DAN GROWTH TERHADAP STRUKTUR MODAL PADA INDUSTRI BARANG KONSUMSI YANG DIDASARI OLEH PECKING ORDER THEORY DAN TRADE-OFF THEORY
}

\author{
Ika Yustina Rahmawati \\ Universitas Muhammadiyah Purwokerto
}

\begin{abstract}
This study aims to determine the effect of profitability, size and growth of the company's capital structure in the consumer goods industry sector based on the pecking order theory and trade-off theory. This research was conducted using the procedure panel data for a sample of 26 consumer goods industry sector companies listed on the Indonesia Stock Exchange during 20092013. The findings of this study is to support H1a, H2b and H3b. based on the results of the analysis of the profitability variable (measured $R O E$ ) there is a negative correlation significant at $\alpha=5 \%$, which means supporting the pecking order theory. The size variable (as measured by total assets) and growth (which was measured by the Market to Book Value) positively associated significant at $\alpha=5 \%$ and $10 \%$, which means supporting the trade-off theory. For the selection method of FEM and REM, researchers used a test in which the capital REM Test Hausmant be an option for the measurement of capital structure (DER, DAR and Working capital) while FEM selected for the measurement of capital structure (Leverage).

Keyword: profitability, size, growth, capital struktur, pecking order theory and trade-off theory
\end{abstract}

\section{ABSTRAK}

Penelitian ini bertujuan untuk mengetahui pengaruh profitabilitas, size dan growth terhadap struktur modal pada perusahaan sektor industri barang konsumsi berdasarkan pecking order theory dan trade-off theory. Penelitian ini dilakukan dengan menggunakan prosedur data panel untuk sampel dari 26 perusahaan sektor industri barang konsumsi yang terdaftar di Bursa Efek Indonesia selama 2009-2013. Temuan dari penelitian ini adalah mendukung H1a, H2b dan H3b. berdasarkan hasil analisis variabel profitabilitas (yang diukur ROE) berubungan negatif signifikan pada tingkat $\alpha=5 \%$, artinya mendukung pecking order theory. Variabel size (yang diukur dengan total asset) dan growth (yang dikur dengan Market to BookValue) berhubungan positif signifikan pada tingkat $\alpha=5 \%$ dan $10 \%$, artinya mendukung trade-off theory. Untuk pemilihan metode FEM dan REM, peneliti menggunakan uji Hausmant Test dimana modal REM menjadi pilihan untuk pengukuran struktur modal (DER, DAR dan Working capital) sedangkan FEM terpilih untuk pengukuran struktur modal (Leverage).

Kata kunci: profitabilitas, size, growth, capital struktur, pecking order theory dan trade-off theory

\section{PENDAHULUAN}

Setiap perusahaan pasti memiliki peluang untuk tumbuh dan berkembang. Dalam proses tersebut perusahaan tentu membutuhkan tambahan modal atau pendanaan, biasanya dalam bentuk utang atau ekuitas. Pendanaan disini bisa bersumber dari internal perusahaan (laba ditahan) dan pendanaan yang bersumber dari external perusahaan (pinjaman dari bank atau menerbitkan ekuitas). Sumber pendanaan yang akan dipilih merupakan keputusan dari manajer perusahaan.

keputusan tentang struktur modal dalam perusahaan merupakan salah satu hal yang sangat penting. Peran manajer dalam keputusan ini adalah untuk memaksimalkan nilai perusahaan. Namun untuk menuju pada maksimalisasi perusahaan merupakan hal yang tidak mudah karena manajer harus melibatkan pilihan terhadap debt dan equity securities yang seimbang. Jika salah dalam memilih mungkin manajer akan kesulitan dalam keuangan sehingga menimbulkan kebangkrutan. (Sheikh and Wang, 2011) 
Sejak Modigliani and Miller (1963) membuat pernyataan tentang irrelevance proposition, maka kunci utama dalam corporate finance telah menjelaskan kondisi di mana struktur modal tidak mempengaruhi nilai perusahaan. Namun bukti empiris mebuktikan bahwa hal ini hanya terbatas di Amerika serikat dan mungkin beberapa negara maju lainnya yang memiliki kelembagaan yang sama sehingga pilihan struktur modal yang tepat akan sangat menarik untuk digali di negara-negara berkembang. (Bhaduri, 2002)

Dalam pemilihan struktur modal yang akan digunakan dalam perusahaan perlu mengenal beberapa konsep theory yang akan mendasari keputusan pendanaan bagi manajer perusahaan. Fokus penelitian ini hanya melihat keputusan pendanaan yang didasari oleh packing order theory atau trade-off theory yang dikemukakan oleh Modigliani dan Miller (1958). Packing order theory menyebutkan bahwa hal pertama yang dilakukan oleh perusahaan adalah meningkatkan modal internal dengan menginvestasikan kembali laba bersih dan penjualan surat berharga jangka pendek. Ketika pasokan dana telah habis, perusahaan akan menerbitkan utang dan mungkin saham preferen. Menerbitkan common stock akan menjadi pilihan terakhir bagi perusahaan. (Brigham and Ehrhardt, 2011). Sedangkan trade-off theory memberikan pandangan bahwa keputusan struktur modal didorong dengan menyeimbangkan manfaat dan biaya utang. (Antonczyk and Salzmann, 2014). Perbedaan mendasar dari kedua theory ini adalah packing order theory berasumsi tidak ada struktur modal yang optimal sedangkan trade-off theory berasumsi untuk membentuk struktur modal yang optimal perlu memasukkan beberapa faktor diantaranya adalah pajak. Berdasarkan latar belakang tersebut maka tujuan dari penelitian ini adalah untuk melihat pengaruh profitabilitas, size dan growth terhadap capital structure pada consumer goods industry berdasarkan pecking order theory dan trade-off theory.

Penelitian ini disusun dengan bagian-bagian sebagai berikut. dalam bagian 2 yang paling menonjol teoritis tentang teori order packing dan teori trade-off, temuan empiris dan kemudian hipotesis. Bagian 3 menggambarkan data dan metodologi yang digunakan dalam penelitian ini. Bagian 4 dikhususkan untuk hasil dan diskusi, dan akhirnya bagian 5 hadir kesimpulan dari penelitian ini.

\section{LITERATURE REVIEW}

\section{a. Teori struktur modal}

Teori struktur modal berawal dari munculnya teori tradisional kemudian berkembang dan lahirlah teori modern dari Modigliani Miller (1985), yang menyatakan tentang teori struktur modal yang tidak relevan. Teori menunjukkan bahwa perusahaan memilih struktur modal tergantung pada atribut yang menentukan berbagai biaya dan manfaat yang terkait dengan utang, ekuitas atau bentuk lain dari pembiayaan (Antonczyk\&salzmann, 2014) Penelitian ini menekankan pada dua teori yaitu pecking order theory dan trade-off theory untuk menjelaskan pilihan struktur modal perusahaan.

Pecking order theory menyebutkan bahwa perusahaan mengikuti urutan peringkat sumber pembiayaan. Urutan peringkat disebabkan oleh variasi dalam tingkat informasi asimetri antara laba ditahan, hutang dan ekuitas dari luar (Myers, 1984; Myers dan Majluf, 1984). Ekuitas memiliki masalah pilihan yang merugikan dan cukup serius antara manajer dan investor sementara utang hanya masalah kecil dalam dalam pilihan yang salah dan laba ditahan merupakan strategi dimana perusahaan bisa menghindari masalah sama sekali.

Alternatif teori lain dalam struktur modal adalah trade-off theory dimana Bankruptcy, financial distress cost dan agency cost merupakan dasar dari trade-off theory. Trade-off theory menyatakan bahwa perusahaan meminjam sampai ke titik di mana penghematan pajak dari tambahan utang yang persis sama dengan biaya yang berasal dari peningkatan kemungkinan financial distress. Berdasarkan kerangka trade-off theory, suatu perusahaan dipandang bisa menetapkan sasaran utang terhadap ekuitas dan 
secara bertahap bergerak ke arah yang menunjukkan bahwa beberapa bentuk struktur modal optimal dapat memaksimalkan nilai perusahaan. (Sheikh and Wang, 2011)

\section{b. Prior studies/ penelitian terdahulu}

1. Sheikh and Wang (2011): Hasil penelitian menunjukkan bahwa profitabilitas, likuiditas, volatilitas pendapatan, dan tangibility (struktur aktiva) berhubungan negatif dengan rasio utang, sedangkan ukuran perusahaan (size) berhubungan positif dengan rasio utang. Non-debt tax shields dan peluang pertumbuhan (growth) tidak terlihat secara signifikan terkait dengan rasio utang. Hasil penelitian ini konsisten dengan prediksi teori trade-off, teori pecking order, dan teori agensi.

2. Syham-Sunder dan Myers (1999): Melihat pengaruh dari dua teori struktur modal yakni teori pecking oder dan trade-off dalam menjelaskan struktur modal. Hasil penelitian menunjukkan bahwa, teori pecking order menjadi faktor utama dan mendeskripsikan perilaku keuangan perusahaan-perusahaan, walaupun teori trade-off memiliki pengaruh, apabila diuji/dites secara independen.

3. Chang, et al (2009): Secara umum melalui simultaneous cause-effect framework, 7 construct yaitu growth, uniqueness, non-debt tax shields, collateral value of assets, profitability, volatility dan industry classification, sebagai penentu struktur modal memiliki efek yang signifikan terhadap struktur modal yang dipilih.

\section{HIPOTESIS}

Ada beberapa faktor yang dapat mempengaruhi struktur modal suatu perusahaan. Riyanto (2001) menyebutkan faktor yang berpengaruh diantaranya adalah susunan aktiva, kadar resiko dari aktiva dan ukuran perusahaan (size). Bringham dan Houston (2002) yang mempengaruhi struktur modal yaitu struktur aktiva, tingkat pertumbuhan (growth) dan profitabilitas.

1. Hubungan profitabilitas dengan struktur modal

Myers dari Donaldson, Brealey dan Myers pada Titman dan Wessels (2002) menunjukkan bahwa perusahaan lebih memilih meningkatkan modal, pertama dari laba ditahan, kedua dari utang, dan ketiga dari penerbitan saham baru. Trade-off teori menunjukkan hubungan positif antara profitabilitas dan leverage karena profitabilitas yang tinggi menunjukkan penggunaan utang dan memberikan insentif bagi perusahaanperusahaan untuk memanfaatkan keuntungan dari perisai pajak atas pembayaran bunga. Teori pecking order menunjukkan bahwa perusahaan lebih memilih untuk menggunakan dana internal bila tersedia dan memilih utang lebih dari ekuitas ketika pembiayaan eksternal diperlukan. Dengan demikian, teori ini menunjukkan hubungan negatif antara profitabilitas (sumber dana internal) dan leverage (sheikh and Wang, 2011). Sehingga terbetuklah hipotesis dibawah ini:

H1a: profitabilitas berpengaruh positif terhadap struktur modal yang didasari oleh tradeoff theory

H1b: profitabilitas berpengaruh negatif terhadap struktur modal yang didasari oleh packing order theory

\section{Hubungan size dengan struktur modal}

Rajan dan Zingales (1995) dalam sheikh and Wang (2011) menemukan hasil yang konsisten dengan prediksi teori trade-off yang menunjukkan bahwa perusahaanperusahaan besar harus meminjam lebih banyak karena perusahaan-perusahaan ini lebih beragam, kurang rentan terhadap kebangkrutan, dan memiliki biaya kebangkrutan relatif lebih rendah. Temuan ini menunjukkan hubungan positif antara ukuran perusahaan dan leverage. Sedangkan teori pecking order menunjukkan hubungan negatif antara ukuran 
perusahaan dan rasio utang, karena masalah asimetri informasi tidak begitu berpengaruh bagi perusahaan-perusahaan besar. Maka terbentuk hipotesis dibawah ini:

$\mathrm{H} 2 \mathrm{a}$ : size berpengaruh positif terhadap struktur modal yang didasari oleh trade-off theory

$\mathrm{H} 2 \mathrm{~b}$ : size berpengaruh negatif terhadap struktur modal yang didasari oleh packing order theory

3. Hubungan growth dengan struktur modal

Menurut teori trade-off, perusahaan yang memiliki peluang pertumbuhan di masa depan, berasal dari intangible assets dibandingkan dengan tangible assets. Temuan ini menunjukkan hubungan negatif antara leverage dan growth (sheikh and Wang, 2011). Untuk perusahaan yang berkembang, masalah agency problem akan cenderung sering terjadi karena lebih fleksibel dalam memilih investasi masa depan. Ini merupakan indikasi dari hubungan negatif antara utang jangka panjang dan pertumbuhan masa depan perusahaan (Bhaduri, 2002). Selanjutnya Myers (1977) dalam Bhaduri (2002) mengemukakan, utang jangka pendek dapat digunakan untuk mengurangi masalah ini; perusahaan tumbuh dapat menggunakan utang jangka pendek bukan utang jangka panjang untuk menghindari biaya agensi tersebut. Maka terbentuklah hipotesis dibawah ini:

H3a: growth berpengaruh positif terhadap struktur modal yang didasari oleh trade-off theory

$\mathrm{H} 3 \mathrm{~b}$ : growth berpengaruh negatif terhadap struktur modal yang didasari oleh packing order theory

\section{METODE PENELITIAN}

\section{a. Data dan sampel}

Data yang digunakan dalam penelitian ini merupakan data sekunder yaitu data yang sudah tersedia dan bisa diperoleh melalui www.idx.go.id. Data tersebut merupakan $\mathrm{ROE}$, total assets, closing stock price, book value (BV), long term liabilities, current liabilities dan total equity. Semua data dalam periode tahunan.

Populasi penelitian yaitu semua perusahaan yang terdaftar di Bursa Efek Indonesia periode 2009-2013 dengan pemilihan sampel perusahaan-perusahaan pada sektor industri barang konsumsi (consumer goods industry) periode 2009-2013, karena jika dilihat nilai capitalization market dari semua sektor yang ada di Bursa Efek Indonesia selama periode penelitian, sektor industri barang konsumsi menempati urutan kedua terbesar setelah sektor finance. Sektor finance tidak menjadi pilihan karena struktur laporan keuangannya berbeda dengan laporan keuangan perusahaan nonkeuangan dan alasan lainnya adalah masalah struktur modal yang dianalisis dalam teori capital structure tidak relevan untuk perusahaan yang bergerak di bidang keuangan.

Sektor industri barang konsumsi memiliki lima sub sektor yaitu sub sektor makanan dan minuman, sub sektor rokok, sub sektor farmasi, sub sektor kosmetik dan keperluan rumah tangga dan sektor peralatan rumah tangga. Semuanya ada 37 perusahaan tetapi yang dijadikan sampel penelitian hanya 26 perusahaan. 8 perusahaan tidak masuk ke dalam periode penelitian sedangkan 3 perusahaan tidak memiliki informasi yang dibutuhkan.

\section{b. Model Penelitian}

Penelitian bertujuan untuk menjelaskan pengaruh profitabilitas, size dan growth terhadap capital structure yang melandaskan pada packing order theory dan trade-off theory pada sektor perusahaan di sektor industri barang konsumsi pada tahun 2009 -2013. Pendekatan untuk menguji pengaruh variabel-variabel tersebut menggunakan persamaan regresi dengan model persamaan berikut: 


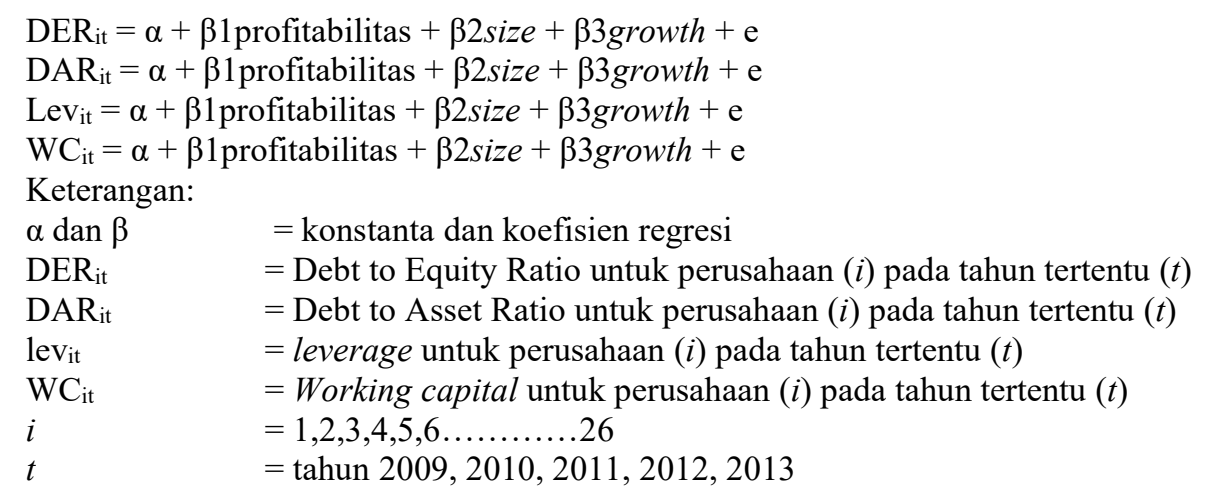

Untuk mengestimasi model penelitian, peneliti menggunakan persamaan sebagai berikut yang tercantum pada definisi operasional disajikan dalam tabel 1 dibawah ini:

Tabel 3.1

Definisi operasional variable

\begin{tabular}{|l|l|l|l|}
\hline Variable & Proxy & Definisi & Sumber \\
\hline Independen & ROE & $\begin{array}{l}\text { Laba sebelum bunga, pajak dan } \\
\text { depresiasi dibagi dengan total aset. }\end{array}$ & $\begin{array}{l}\text { Deesomsak et al } \\
(2004)\end{array}$ \\
\hline Profitabilitas & Total aset & Logaritma natural dari total aset & $\begin{array}{l}\text { Titman \& } \\
\text { Wessles (1988) }\end{array}$ \\
\hline Size & $\begin{array}{l}\text { Market to } \\
\text { Book value }\end{array}$ & $\begin{array}{l}\text { Closing stock price dibagi dengan } \\
\text { book value (BV) }\end{array}$ & $\begin{array}{l}\text { De Jong et al } \\
(2004)\end{array}$ \\
\hline Dependen & \multicolumn{3}{|l|}{} \\
\hline $\begin{array}{l}\text { Capital } \\
\text { structure }\end{array}$ & DER & Jumlah utang perusahaan & Bhaduri (2002) \\
\hline & DAR & Total liabilities dibagi total assets & Bhaduri (2002) \\
\hline & $\begin{array}{l}\text { Working } \\
\text { capital }\end{array}$ & $\begin{array}{l}\text { Long term liability dibagi dengan } \\
\text { total equity } \\
\text { equity }\end{array}$ & Bhaduri (2002) \\
\hline
\end{tabular}

\section{c. Estimasi}

Data yang dikumpulkan dalam penelitian ini sejumlah 26 perusahaan dengan cara cross section dan diikuti pada periode 5 tahun pengamatan yaitu periode tahun 20092013, data ini dikenal dengan data panel. Estimasi dengan menggunkan data panel ini peneliti dapat melihat perubahan tingkat profitabilitas, size dan growth yang terjadi pada sampel penelitian. Widarjono (2013) menyebutkan ada 3 pendekatan metode yang bisa digunakan untuk mengestimasi model regresi dengan data panel yaitu pendekatan Common Effect, Fixed Effect, Random Effect

\section{HASIL DAN PEMBAHASAN}

Bagian ini menunjukkan hasil estimasi dan pembahasan dari penemuan empiris. Dapat dilihat pada tabel 2 dibawah ini yang menyajikan deskriptif statistik dari perbandingan antara faktor-faktor yang mempengaruhi struktur modal (profitabilitas dengan proxy ROE, size dan growth terhadap DER, DAR, Leverage dan working capital). 
Tabel 4.1

Deskriptif analisis

\begin{tabular}{|c|c|c|c|c|c|}
\hline Variabel & Observation & Mean & SD & Minimun & Maximum \\
\hline ROE & 130 & 18.72962 & 23.53703 & -52.98 & 125.81 \\
\hline SIZE & 130 & 14.26371 & 1.650816 & 11.34186 & 18.17341 \\
\hline GROWTH & 130 & 4.2809 & 7.671256 & 0.172837 & 46.62674 \\
\hline DER & 130 & 0.838692 & 0.716025 & 0.05 & 5.65 \\
\hline DAR & 130 & 0.398615 & 0.18185 & 0.04 & 1.21 \\
\hline LEV & 130 & 0.247248 & 0.247248 & 0.019649 & 2.272026 \\
\hline Working capital & 130 & 0.584348 & 0.489272 & 0.031066 & 3.372986 \\
\hline
\end{tabular}

Sumber: data diolah, 2014

Hasil penelitain menunjukkan bahwa dari pengaruh faktor-faktor seperti profitabilitas, size dan growth terhadap struktur modal yang didasari oleh trade-off theory dan pecking order theory, maka dapat dilihat hasil statistik pada tabel 3 dibawah ini:

Tabel 4.2

Estimasi profitabilitas, size dan growth terhadap struktur modal perusahaan pada sektor industri barang konsumsi (metode PLS)

\begin{tabular}{|c|c|c|c|c|}
\hline Variabel & & & tur modal & \\
\hline $\begin{array}{l}\text { Variabel dependen } \\
\text { Independen }\end{array}$ & DER & DAR & Leverage & $\begin{array}{l}\text { Working } \\
\text { capital }\end{array}$ \\
\hline Profitabilitas & $\begin{array}{l}-0.029 \\
(0.00)^{*}\end{array}$ & $\begin{array}{l}-0.004 \\
(0.00)^{*}\end{array}$ & $\begin{array}{l}-0.011 \\
(0.00)^{*}\end{array}$ & $\begin{array}{l}-0.018 \\
(0.00)^{*}\end{array}$ \\
\hline Size & $\begin{array}{l}0.090 \\
(0.01)^{*}\end{array}$ & $\begin{array}{l}0.015 \\
(0.09)^{* *}\end{array}$ & $\begin{array}{l}0.043 \\
(0.02)^{*}\end{array}$ & $\begin{array}{l}0.053 \\
(0.01)^{*}\end{array}$ \\
\hline Growth & $\begin{array}{l}0.099 \\
(0.00)^{*}\end{array}$ & $\begin{array}{l}0.019 \\
(0.00)^{*}\end{array}$ & $\begin{array}{l}0.024 \\
(0.00)^{*}\end{array}$ & $\begin{array}{l}0.074 \\
(0.00)^{*}\end{array}$ \\
\hline $\mathrm{R}^{2}$ & 0.307 & 0.227 & 0.141 & 0.386 \\
\hline F test & $0.00^{*}$ & $0.00^{*}$ & $0.00 *$ & $0.00 *$ \\
\hline
\end{tabular}

$*=$ signifikan $5 \%$

$* *$ = signifikan $10 \%$

Sumber: data diolah, 2014

Dari hasil analisis dari variabel pada penelitian ini maka ditemukan hasil bahwa profitabilitas berhubungan negatif dan signifikan pada tingkat $\alpha=5 \%$, artinya H1a terdukung dan H1b ditolak. Dimana maknanya adalah perusahaan pada industri consumer goods memiliki tingkat profitabilitas yang tinggi, sehingga sesuai dengan pecking order theory perusahaan mengambil keputusan dalam berhutang memperhitungkan hierarki pembiayaan perusahaan, dan pada kenyataannya saat perusahaan memiliki profitabilitas tinggi cenderung untuk tidak berhutang.

Untuk variabel size dan growth memiliki dampak positif dan signifikan terhadap struktur modal pada tingkat $\alpha=5 \%$ dan $10 \%$. Temuan ini konsisten dengan implikasi dari trade-off theory yang menunjukkan bahwa perusahaan-perusahaan besar harus beroperasi pada tingkat utang yang tinggi karena kemampuan mereka untuk diversifikasi risiko dan mengambil manfaat dari tax shield atas pembayaran. Artinya $\mathrm{H} 2 \mathrm{~b}$ dan $\mathrm{H} 3 \mathrm{~b}$ terdukung dan H2a serta H3a ditolah. Dimana maknanya adalah perusahaan pada industri consumer goods lebih merujuk pada trade-off theory. Karena perusahaan yang sudah besar dan maju memiliki tingkat pertumbuhan yang tinggi sehingga perlu menggnakan hutang dalam pembiayaan perusahaan karena perusahaan yang besar rentan terhadap kebangkrutan. 
Tahap analisis selanjutnya pada penelitian ini adalah membandingkan model Fixed Effect (FEM) dan Random Effect (REM), dengan melihat tingkat probabilitas dari uji hausman test. Tabel 4 dan 5 dibawah ini menyajikan hasil statistik dari FEM dan REM sedangkan untuk uji hausman test disajikan dalam tabel 6.

Tabel 4.3

Estimasi profitabilitas, size dan growth terhadap structur modal perusahaan pada sektor industri barang konsumsi (Model Fixed Effect)

\begin{tabular}{|l|l|l|l|l|}
\hline \multirow{2}{*}{$\begin{array}{c}\text { Variabel } \\
\text { Variabel } \\
\text { dependen }\end{array}$} & \multicolumn{4}{c|}{ Estimasi Fixed effect model } \\
\cline { 2 - 5 } & DER & \multicolumn{1}{c|}{ DAR } & \multicolumn{1}{c|}{ Leverage } & Working capital \\
\hline Profitabilitas & & & & \\
& -0.028 & -0.001 & -0.013 & -0.018 \\
& $(0.00)^{*}$ & $(0.03)^{*}$ & $(0.00)^{*}$ & $(0.00)^{*}$ \\
\hline Size & -0.259 & -0.002 & -0.310 & 0.053 \\
& $(0.122)$ & $(0.87)$ & $(0.00)^{*}$ & $(0.01)^{*}$ \\
\hline Growth & 0.091 & 0.016 & 0.029 & 0.074 \\
& $(0.00)^{*}$ & $(0.00)^{*}$ & $(0.00)^{*}$ & $(0.00)^{*}$ \\
\hline $\mathrm{R}^{2}$ & 0.753 & 0.855 & 0.739 & 0.386 \\
\hline F statistik & $0.00^{*}$ & $0.00^{*}$ & $0.00^{*}$ & $0.00^{*}$ \\
\hline
\end{tabular}

$*$ = signifikan $5 \%$

** = signifikan $10 \%$

Sumber: data diolah, 2014

Tabel 4.4

Estimasi profitabilitas, size dan growth terhadap structur modal perusahaan pada sektor industri barang konsumsi (Model Random Effect)

\begin{tabular}{|c|c|c|c|c|}
\hline \multirow{2}{*}{$\begin{array}{c}\text { Variabel } \\
\text { dependen } \\
\text { Variabel independen }\end{array}$} & \multicolumn{4}{|c|}{ Random Effect Model } \\
\hline & DER & DAR & Leverage & Working capital \\
\hline Profitabilitas & $\begin{array}{l}-0.025 \\
(0.00)^{*}\end{array}$ & $\begin{array}{l}-0.001 \\
(0.02)^{*}\end{array}$ & $\begin{array}{l}-0.010 \\
(0.00)^{*}\end{array}$ & $\begin{array}{l}-0.015 \\
(0.00)^{*}\end{array}$ \\
\hline Size & $\begin{array}{l}0.053 \\
(0.36)\end{array}$ & $\begin{array}{l}-0.002 \\
(0.87)\end{array}$ & $\begin{array}{l}-0.003 \\
(0.91)\end{array}$ & $\begin{array}{l}0.052 \\
(0.17)\end{array}$ \\
\hline Growth & $\begin{array}{l}0.088 \\
(0.00)^{*}\end{array}$ & $\begin{array}{l}0.016 \\
(0.00)^{*}\end{array}$ & $\begin{array}{l}0.023 \\
(0.00)^{*}\end{array}$ & $\begin{array}{l}0.064 \\
(0.00)^{*}\end{array}$ \\
\hline $\mathrm{R}^{2}$ & 0.302 & 0.254 & 0.140 & 0.347 \\
\hline F statistik & $0.00 *$ & $0.00 *$ & $0.00 *$ & $0.00 *$ \\
\hline
\end{tabular}

$*=$ signifikan $5 \%$

$* *$ = signifikan $10 \%$

Sumber: data diolah, 2014

Jika membandingkan analisis statistik antara FEM dan REM yang menunjukkan konsistensi adalah pada variabel profitabilitas dan growth, hasilnya tetap mendasari pada pecking order theory untuk variabel profitabilitas dan trade-off theory untuk variabel growth. Adapun variabel size pada model FEM berhubungan negatif tidak signifikan terhadap DER dan DAR sebagai proxy dari struktur modal dan hubungan negatif signifikan terhadap leverage, sedangkan yang mendukung konsistensi landasar trade-off theory yaitu working capital sebagai proxy struktur modal yang berhubungan positif signifikan pada tingkat $\alpha=$ $5 \%$.

Untuk model REM tidak menunjukkan konsistensi hasil sesuai dengan implikasi dari trade-off theory dan mennjukkan hubungan yang tidak signifikan dari semua proxy 
struktur modal. Peneliti melakukan tahapan akhir untuk memilih metode FEM atau REM dengan melakukan uji hausmant test seperti dilihat dalam tabel 6 dibawah ini:

Tabel 4.5

Uji hausmant test

\begin{tabular}{|l|l|l|l|l|}
\hline & DER & DAR & Leverage & Working capital \\
\hline Probabilitas & 0.1784 & 0.1808 & $0.0021^{*}$ & 0.7357 \\
\hline
\end{tabular}

$*=$ signifikan $5 \%$

** = signifikan $10 \%$

Sumber: data diolah, 2014

Dari hasil probabilitas uji hausmant test memberikan bukti bahwa model REM yang terpilih untuk pengujian pengaruh faktor profitabilitas, size dan growth terhadap struktur modal (proxy DER, DAR dan working capital) dengan didasari oleh pecking order theory dan trade-off theory. Karena syarat diterimanya memilih model REM ketika tingkat profitabilitasnya lebih besar dari $\alpha=5 \%$. Hanya Leverage yang cocok untuk model FEM karena hasilnya signifikan pada tingkat $\alpha=5 \%$. Karena syarat memilih model FEM ketika tingkat probabilitasnya lebih kecil dari alpha.

\section{KESIMPULAN}

Peneliti dapat menyimpulkan hasil pembahasan penelitian ini dengan melihat bahwa perusahaan pada sektor industri consumer goods lebih memilih menggunakan labanya (profitabilitas yang diukur dengan ROE) untuk dipergunakan terlebih dahulu dalam melakukan pembiayaan bagi perusahaan. Hal ini sejalan dengan pecking order theory dimana saat perusahaan melakukan hierarki pembiayaan dalam pngambilan keputusannya.

Jika dilihat dari capitalization marketnya, sektor industri consumer goods menduduki peringkat nomor dua, sehingga tidak mengerankan jika sub sektor yang ada didalamnya merupakan perusahaan yang sudah besar dengan tingkat perumbuhan yang tinggi pula. Selaras dengan hasil penelitian ini variabel size (yang diukur dengan total asset) dan variabel growth (yang diukur dengan book value), maka perusahaan pada industri consumer goods lebih memilih untuk menerapkan trade-off theory.

Keterbatasan dalam penelitian ini adalah periode penelitian bisa lebih diperpanjang lagi (lebih dari 5 tahun), dan observasi bisa dalam harian atau bulanan sehingga bisa mendapatkan jumlah observasi yang lebih banyak. Variabel penelitian yang mempengaruhi struktur modal masih banyak yang perlu dieksplorasi lagi misalnya tangible atau intangible assets, volatility atau non-debt tax shields, sehingga bisa lebih memperkaya lagi hasil penelitian.

Akhirnya peneliti menyimpulkan setiap perusahaan pasti ingin memiliki struktur modal yang optimal tapi pada kenyataannya banyak faktor yang mempengaruhi keputusan pembiayaan dalam perusahaan. Pecking order theory dan trade-off theory mungkin bisa menjadi alternatif dalam pengambilan keputuasan tentunya dengan memperhatikan kondisi perusahaan tersebut serta kebijakan-kebijakan yang diambil oleh manajer.

\section{DAFTAR PUSTAKA}

Antonczyk, Ron C and Salzmann, Astrid J. 2014. Overconvidence and Optimism: The Effect of National Culture on Capital Structure. Research in International Business and Finance 31. 132-151 
Bhaduri, Saumitra N. 2002. Determinants of Corporate Borrowing: Some Evidence from the Indian Corporate Structure. Journal of Economics and Finance. Vol 26. Number 2

Booth, Laurence., Aivazian, Varouj., Demirguc-Kunt., Asli, dan Maksimovic, Vojislav. 2001. Capital structure in Developing Countries. Journal of Finance 56. No 1. Halaman 87-130.

Brigham, Eugene F and Ehrhardt, Michael C. 2011. Financial Management: Theory and Practice. Thirteenth Edition. South-Western Cengage Learning. USA

Brigham, Eugene F and Houston, Joel F. 2007. Dasar-Dasar Manajemen Keuangan (Essentials of Financial Management). Salemba empat. Jakarta

Brigham, Eugene F. dan Houston Joel F., 2001. Manajemen Keuangan. Edisi VIII. Erlangga, Jakarta.

Chang, Chingfu., Lee Alice C., Lee Cheng F., 2009. Determinants of capital structure choice: A structural equation modeling approach. The Quarterly Review of Economics and Finance 49 (2009) 197-213.

Myers, Stewart C., 1984. The Capital Structure Puzzle. Journal of Finance 39, Halaman 575-592.

Myers, S.C., Majluf, N., 1984. Corporate Financing and Investment Decisions. When Firm Have Information That Investor Do Not Have. Journal of Finance economic. 13, 187-221.

Riyanto, Bambang. 2001. Dasar-dasar Pembelanjaan Perusahaan. Edisi Keempat. BPFE-UGM. Yogyakarta.

Sheikh, Nadeem A and Wang, Zongjun. 2011. Determinants of capital structure an empirical study of firms in manufacturing industry of Pakistan. Managerial Finance Vol. 37 No. 2, pp. $117-133$

Shyam-Sunder, Lakshmi and Myers, Stewart C., 1998. Testing Static Trade Off Against Pecking Order Model of Capital Structure. Journal of Financial Economics 51. Halaman 219-244.

Widarjono, Agus. 2013. Ekonometrika pengantar dan aplikasinya. Edisi keempat. UPP STIM YKPN. Yogyakarta 